\title{
REVIEW JURNAL PENELITIAN
}

KOMODIFIKASI MODEL ENDORSE DALAM INDUSTRI BUDAYA FASHION DAN KOSMETIKA (Hiperrealitas Fashion Endorse pada Produk Kosmetik dan Busana Remaja di Media Sosial Instagram)

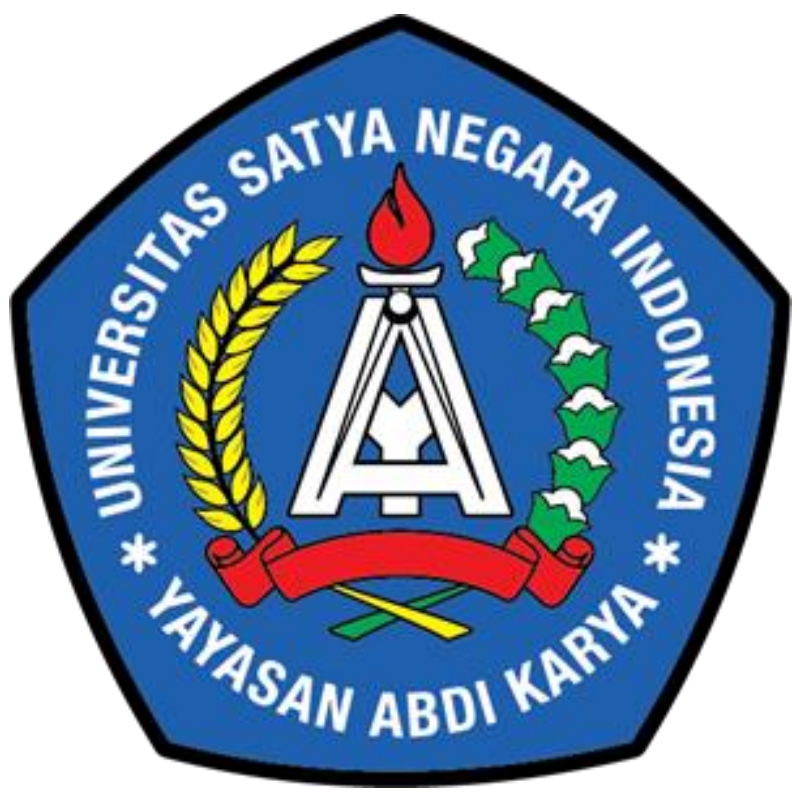

Disusun Oleh:

Ahmad Fathoni (180900076)

Dosen Pembimbing:

Radita Gora Tayibnapis,S.Sos,M.M

UNIVERSITAS SATYA NEGARA INDONESIA

FAKULTAS ILMU SOSIAL DAN ILMU POLITIK 


\section{KATA PENGANTAR}

Alhamdulillahirabbil 'alamin, rasa syukur kami panjatkan ke hadirat Tuhan yang Maha Kuasa yang telah melimpahkan rahmat-Nya berupa kesehatan, kesempatan serta pengetahuan sehingga Makalah Review Jurnal Teori Komunikasi tentang 'KOMODIFIKASI MODEL ENDORSE DALAM INDUSTRI BUDAYA FASHION DAN KOSMETIKA (Hiperrealitas Fashion Endorse pada Produk Kosmetik dan Busana Remaja di Media Sosial Instagram)' ini bisa selesai sesuai dengan waktu yang telah ditentukan.

Saya berharap agar makalah ini bisa bermanfaat untuk menambah pengetahuan rekan-rekan mahasiswa pada khususnya dan para pembaca umumnya tentang KOMODIFIKASI MODEL ENDORSE DALAM INDUSTRI BUDAYA FASHION DAN KOSMETIKA (Hiperrealitas Fashion Endorse pada Produk Kosmetik dan Busana Remaja di Media Sosial Instagram) yang merupakan salah satu bagian dari mata kuliah Teori Komunikasi.

Mudah-mudahan makalah sederhana yang telah saya susun ini bisa dengan mudah dipahami oleh siapapun yang membacanya. Sebelumnya saya meminta maaf bilamana terdapat kesalahan kata

atau kalimat yang kurang berkenan. Serta tak lupa kami juga berharap adanya masukan serta kritikan yang membangun dari Anda demi terciptanya makalah yang lebih baik lagi.

Jakarta,16 September 2020 


\section{DAFTAR ISI}

Kata Pengantar ......................................................................................................................................

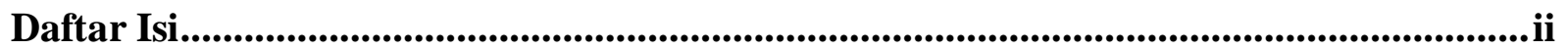

\section{BAB I PENDAHULUAN}

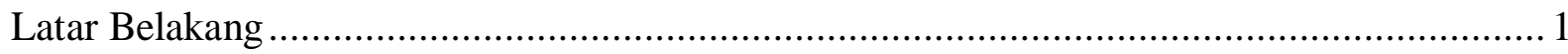

\section{BAB II PEMBAHASAN}

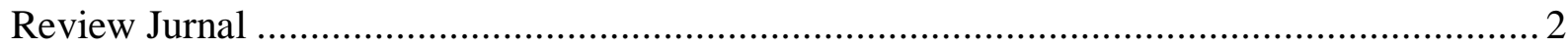

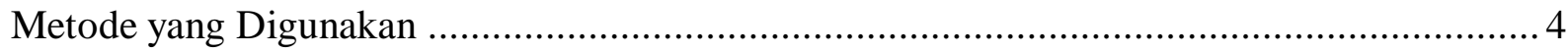

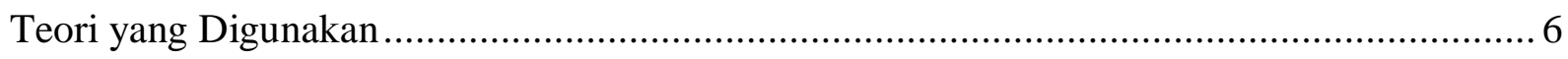

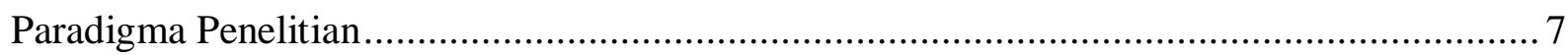

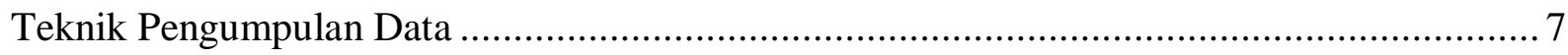

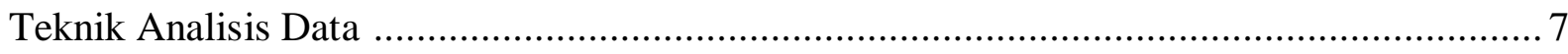

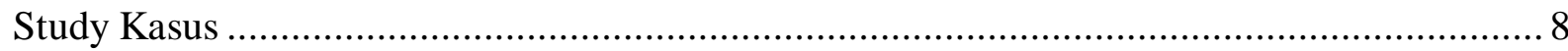

\section{BAB III PENUTUP}

Kesimpulan...........................................................................................................................................

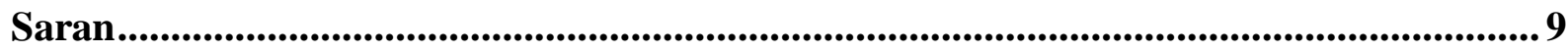

Daftar Pustaka ........................................................................................................................................... 10 


\section{BAB I \\ PENDAHULUAN}

\section{Latar Belakang}

Pengguna social mobile dan social media aktif yang terusmeningkat mengingat pada tahun 2018, pengguna media sosial di dunia mencapai 3.196 Miliar dari penetrasi $42 \%$, menurut data Hootsuite we are social, serta pengguna internet aktif pada tahun 2018 sebesar

4.021 Miliar daripenetrasi 53\% dan juga beriringan dengan terus bertambahnya situs jual beli online dengan menawarkan sharing business economy untuk keuntungan dan bagi hasil, serta situs yang digunakan bukan hanya digunakan untuk kepentingan pebisnis lama, namun juga bisa diterapkan bagi para pebisnis muda dan amatir yang semakin dimudahkan dengan beragam teknologi komunikasi dan informasi digital serta kemudahan fasilitas penyedia fitur-fitur lengkap dan baru didalamnya, sehingga juga memudahkan bagi produsen untuk bisa terus kontak dengan penjualnya.

Saya memilih judul jurnal ini karena dari jurnal ini menarik buat saya untuk dibahas. Dan model yang untuk mengendorse cukup menarik untuk dikaji lebih lanjut. 


\section{BAB II \\ PEMBAHASAN}

\section{Review Jurnal}

Industri fashion dan kosmetika hingga saat ini masih merajai item-item produk yang ditawarkan di dalam e commerce. Vendor-vendor baru terus bermuncula di situs jual-beli produk mengingat aktivitas atau kegiatan promosi di media sosial saat ini gencar dilakukan mengingat beberapa pihak menilai bahwa promosi yang dilakukan di media sosial efektif dan pengguna sosial media aktif terus bertambah dan berkembang. Hal ini tentunya juga menjadi bagian dari individu yang paritisipatif dalam kegiata jual beli secara online lantaran internet adalah ladang bisnis baru bagi pebisnis muda atau pebisnis pemula. Selain itu aktivitas penawaran produk atau perdagangan di media sosial mudah untuk dilakukan lantaran adanya bentuk penawaran yang dilakukan tanpa memperlihatkan wajah si produsen, kemudian platfom teknologi yang digunakan pun juga efisien dengan perangkat mobile technology dengan harga yang beragam dan juga terjangkau. Sehingga dari sini memudahkan bagi para produsen baru untuk memasarkan produknya.

Country Head Google Indonesia, Rudy Ramawy, mengatakan kebiasaan ini karena tidak ada perbedaan kelas antar masyarakat dalam membeli baju melalui transaksi online. Masyarakat kelas menengah bawah bisa saja membeli baju melalui toko online. Tidak ada strata kelas dalam pembelian barang fashion melalui e-commerce, jadi mereka biasanya sungkan ketika membeli di Mall yang mewah, dan menjadi lebih luwes ketika membeli barang di toko online. Cara berbelanja melalui online juga mengubah kebiasaan masyarakat indonesia dalam berbelanja. Perkembangan internet mengubah cara pandang seseorang dalam membeli barang. Selain itu, para responden mengatakan bahwa belanja melalui toko online dianggap lebih mudah. Sekitar $72 \%$, menurut data google Indonesia tahun 2017, mengatakan bahwa responden mengaku mempersingkat waktu ketika melakukan belanja online atau online shopping.

Banyak alasan lainnya, seperti dapat dikirimkan ke rumah dan tidak harus berpergian ke berbagai daerah, ini yang membuat pertumbuhan bagi transaksi online. Berdasarkan data Asosiasi Pengusaha Ritel Indonesia, pelaku ritel di Indonesia maupun di berbagai negara saat ini sedang berupaya merangkul pendekatan multichannel atau offline- to-online $(\mathrm{O} 2 \mathrm{O})$. Hal ini dilakukan untuk memenuhi ekspektasi pelanggan sekaligus memenangkan perebutan pangsa pasar.

Fashion dan kosmetika, bagi masyarakat modern tidak lagi dianggap sebagai pemenuhan kebutuhan sekunder, namun juga dipandang sebagai kebutuhan primer yang harus terpenuhi. Sehingga penawaran trend busana-busana baru dengan beragam variasi atau model-model yang beragam dan dari berbagai versi, memudahkan bagi para konsumen atau khalayak luas dalam memilih produk meskipun penawaran produk dan jenis busana atau kosmetik yang ditawarkan 
memiliki banyak jenis dan beragam.

Upaya memenangkan persaingan bisnis tersebut, maka produsen baju pun berlomba-lomba untuk membuat media promosi dengan desain iklan yang menarik dimedia digital, eye catching serta menggunakan model-model yang memiliki perawakan dari wajah atau badan yang sesuai dengan penangkapan kamera atau dikenal dengan istilah camera face dan memiliki perawakan yang menjual. Sehingga dengan begitu dapat mendukung produk agar mudah terjual dengan terus mendengungkan brand (merek) produk di media komunikasi massa digital karena ada ketertarikan konsumen atau calon konsumen terhadap model ataupun produk yang dijual.

Penggunaan model-model endorse pada produk busana, kosmetik dan lain sebagainya kini mulai dipopulerkan kembali sejak adanya kegiatan marketing elektronik dengan menggunakan media online. Endorse sendiri sebenarnya bukan praktik baru dalam aktivitas marketing. Apabila mengacu pada vendor-vendor lama atau yang sudah menjadi pebisnis lama di bidang fashion dan kosmetika, biasanya paradigma konvensional yang digunakan adalah dengan berpromosi memanfaatkan model terkenal atau selebritis terkenal. Adapula yang meneggunakan model berkelas yang memiliki potensi fisik yang memadai, glamour serta dari segi perwajahan yang benar-benar memiliki nilai berkelas atau menunjang dari sisi karirnya.

Seiring berjalannya waktu dengan adanya media sosial dan perangkat media digital yang mudah dijangkau atau dimiliki oleh masyarakat dari semua kalangan, potensi masyarakat untuk membangun brand pun juga dilakukan dengan cara beragam dan kreatif. Bahkan dengan adanya media sosial, blog dan lain sebagainya yang terkoneksi dengan jaringan online, kegiatan promosi produk pun mudah dilakukan serta membangun publisitas produknya dengan gaya storytelling. Bahkan strategi promosi dengan low budget (pembiayaan murah) pun beragam serta dengan cara yang kreatif, sehingga pesan dalam kegiatan promosi pun menjadi bernilai persuasif serta cepat diterima dan ditangkap oleh khalayak luas, mengingat pengguna ponsel pintar di Indonesia juga terus meningkat dan tingkat konsumsi khalayak yang juga terus meningkat, sejak diperkenalkannya beragam aplikasi situs online di ponsel dan juga para akun pengguna media sosial yang terus meningkat.

Kreatifitas para produsen busana dan kosmetik pun tak canggung dalam menampilkan model endorse biasa, tak dikenal atau bukan figur publik untuk menjadi model busana dan kosmetik yang dipromosikan lewat media sosial, mengingat free promotion di media sosial yang diutamakan untuk menekan budget promosi dan memperkenalkan brand ke masyarakat. Model endorse biasanya menggunakan objek manusia yang secara perwajahannya merupakan perwajahan kamera (camera face), perawakan yang stabil dan memiliki rupa atau gaya perawakan yang menunjang untuk promosi produk dengan mengenakan busana dari produk yang akan dipasarkan, kemudian dimuat atau ditampilkan di media sosial atau portal web online e commerce. 
Produk fashion di media instagram sebagai sarana promosinya, termasuk menjadikan publik amatir sebagai model endorse untuk produk fashion dan kosmetika. Namun kegandrungan para remaja menjadi model ini kemudian terlihat sebagai bentuk pemanfaatan tubuh sebagai 'alat jual' untuk mempromosikan produk dan meningkatkan nilai jual produk yang dipromosikan. Komodifikasi adalah proses yang erat di kaitkan dengan kapitalisme di mana objek-objek, kualitas-kualitas, dan tanda-tanda diubah menjadi komoditas. Komoditas sendiri dipahami sebagai sebauh barang yang tujuan utama keberadaannya adalah untuk dijual di pasar.

Dalam jurnal tersebut menggunakan produk Nature Republik dengan model wanita hijab dalam pembahasannya.

Produk Nature Republic adalah produk kosmetik sebagai cream pembersih selain mengundang fanatisme pelanggan dalam jumlah besar hingga mengantri dari sisi penjualan termasuk maraknya kasus pemalsuan produk ini sehingga produk ini menjadi incaran distributor dan menggunakan endorse sebagai bagian dari pendukung alat jualnya.

\section{METODE YANG DIGUNAKAN}

Dalam penelitian jurnal tersebut menggunakan metode Semiotika. Semiotik atau penyelidikan simbol-simbol membentuk tradisi pemikiran yang penting dalam teori komunikasi. Tradisi semiotik terdiri atas sekumpulan teori tentang bagaimana tanda-tanda merepresentasikan benda,ide,keadaan,situasi,perasaan dan kondisi di luar tanda-tanda itu sendiri. Penyelidikan tanda-tanda tidak hanya memberikan cara untuk melihat komunikasi,melainkan memiliki pengaruh yang kuat pada hampir semua perspektif yang sekarang diterapkan pada teori komunikasi.

Semiotika menunjukkan bahwa apa yang kita anggap sebagai "alami" atau "jelas" dalam wacana publik perlu dipertimbangkan dalam konteks. Artinya,nilai-nilai kita dan struktur keyakinan yang sering merupakan akibat dari apa yang telah diwariskan dari generasi ke generasi (tradisi). Apa yang di anggap sebagai sesuatu yang "diberikan" tahun lalu hanya mungkin tidak seperti itu hari ini. Semiotika menentang gagasan bahwa kata-kata memiliki makna yang sesuai;memang,katakata berubah maknanya seiring dengan orang yang menggunakan kata-kata tersebut juga berubah.

Contoh simple dari teori ini seperti sebuah cincin di jari manis tangan kiri adalah tanda sudah menikah. Seorang anak kecil menangis dikuburan adalah tanda kesedihan ditinggal seseorang.

Dalam jurnal maka dapat dijelaskan bahwa aspek tanda yang digunakan pada produk iklan kosmetika Nature Republic dilihat dari tiga sisi, yaitu Teks, warna dan figure. Menurut penulis teks 
pada iklan Nature Republic versi wanita hijab bertuliskan "Pakai Aloevera?" sebagai sebuah teks pertanyaan kata "pakai" yang berarti menggunakan.

Sementara "Aloevera" sebagai sinonim dari tanaman lidah budaya. Dalam aspek Denotasi bahwa tanaman yang digunakan untuk perawatan herbal yang baik untuk kesehatan tubuh dan digunakan untuk perawatan pada kulit wajah dan rambut. Pada tanda ini dimunculkan sebagai upaya untuk mengajak masyarakat atau audiens berpikir tentang kegunaan tanaman lidah buaya. Pada teks berikutnya adalah "Muka kinclong bak artis Korea?" Pada pertanyaan masing-masing kata pada "Muka" berarti wajah yang dimaknai secara fisik atau "badan" bukan diartikan sebagai diri. Pada bahasa iklan hendaknya menggunakan penggunaan kata-kata baku yang dalam Kamus Besar Bahasa Indonesia (KBBI) penggunaan kata baku merujuk pada "Wajah" sebagai pembentukan pengucapan kata yang sebenarnya dan digunakan pada konten tertentu. Pada iklan ini terdapat kekeliruan penggunaan kata ' $m u k a$ ' yang secara harafiah dimaknai sebagai diri seperti harga diri. Sementara penggunaan kata 'wajah' adalah fisik atau badan manusia. Kemudian pengunaan kata 'kinclong' yang secara sinonim adalah mengkilap.

Dengan makna denotasinya dapat diartikan bersih, atau tidak kusam. Hal ini juga melanggar dari sisi estetika bahasa dan eika yang tidak termasuk dalam pemenuhan kaidah bahasa yang baku seperti "wajah bersih" atau "wajah terlihat bersih". Sehingga makna dalam iklan pun menjadi jelas dan tidak rancu dengan persoalan estetika bahasa maupun etika penggunaan kata. Subjek teks perlu memandang jarak dengan kahalayak sehingga teks dapat bersifat netral. Jika teks mendekatkan pada segment tertentu, maka ada kecenderungan teks berpihak sehingga nilai kegunaan dari teks menjadi hilang.

Penggunaan kata "kayak artis Korea” kata "kayak” dapat diartikan "seperti” yang juga berlaku interpretasi umum "sama halnya" atau "menyerupai". Kemudian kata "artis" bisa diartikan sebagai pekerja seni. Namun pada kata artis disini bukan dimaknai sebagai pekerja seni secara luas, melainkan memfokuskan pada "artis sebagai selebiritis" atau dalam makna denotasinya adalah orang terkenal atau figur ternama. Hal ini menjadi berhubungan dalam penggunaan kalimat pertanyaan bahwa aspek estetika penggunaan kata, pemilihan kata, serta etika yang digunakan dalam berbicara tidak memperhatikan aspek etika dan estetikanya. Dan terlalu mengkaitkan dengan "artis korea”. Dalam hal ini, ada unsur 'pemujaan' terhadap sosok artis Korea. 
Pada latar warna secara keseluruhan menggunakan warna latar hijau muda sebagai warna alam dalam pemaknaan denotasi yang identik dengan warna hijau dan juga warna daun. Namun warna hijau juga mengacu pada warna tanaman seperti lidah buaya yang notabene berwarna hijau muda sebagai kualitas tanaman lidah buaya yang baik.

Figur endorse pun juga tidak relevan dalam menggunakan figur perempuan berhijab dengan busana hitam. Sehingga tidak ada estetika antara penempatan figur dengan warna latar pada visual media promosinya. Begitu pula penempatan endorse pun cenderung dipaksakan dengan tidak memperhatikan estetika penampilan maupun tidak menempatkan perwajahan yang camera face dan tidak menyesuaikan konsepsi perwajahan Korea

Selain produk nature republic, peneliti juga membahas Produk fashion pria Roughneck versi pria remaja dengan konsep street "jalanan”. Menurut peneliti model Endorse pada komposisi yang estetis, dan tidak memandang sinkronisasi komposisi ojek latar dengan subjek yang difoto. Pada tanda objek yang terlihat pada latar penuh dengan partisi benda-benda sekunder seperti kursi, atau tanaman dan sebuah ruangan sehingga terlihat gaya semi modern antara saat ini dengan jaman dahulu (retro). Adapun penempatan posisi endorse juga tidak menempatkan posisi model secara teratur sehingga estetika model ada kecenderungan tidak bisa menampilkan pasar fashon yang sebagaimana mestinya.

\section{TEORI YANG DIGUNAKAN}

Teori yang digunakan dalam penelitian ini menggunakan Teori Simulacra menurut perspektif Baudrillad dalam kebudayaan modern. Dalam budaya populer dianggap lebih rendah daripada budaya tinggi Seni dan musik klasik di satu sisi dan budaya rakyat yang otentik di sisi lain. Para pembela distingsi (pembeda) antara budaya tinggi dan budaya populer mendasarkan pada pembeda yang dibuat dan ditunjukkan oleh budaya populer. Budaya populer seringkal dituduh menstandarisasikan dan memerosotkan kualitas seni dan budaya sehingga seni-budaya konformis. Dalam study kasus,kajian simulacra, dapat terlihat bahwa produk fashion maupun kosmetika ini membangun pesan yang bersifat persuasif untuk membentuk suatu simulasi masyarakat yang terlihat seolah tidak membedakan antara realitas fakta maupun diluar realitas. Upaya menanamkan kesadaran kepada konsumen bahwa produk semacam kosmetika nature republic memberikan keyakinan pada masyarakat dengan menggunakan produk tersebut, maka dapat memberikan perwajahan yang bersih seperti halnya figur Korea.

Hal ini pun sesuai dengan perspektif fanatisme masyarakat konsumen terhadap nilai-nilai 
konsumtif produk dalam memilih produk. Begitu pula dengan produk Roghneck yang memberikan tentang perspektif busana remaja yang bernuansa sederhana dan bisa digunakan dalam segala situasi. Sehingga bagi remaja, untuk gaya berbusana sederhana adalah upaya untuk membangun identitas diri, namun di satu sisi juga mengajak remaja untuk hidup dalam dunai gaya (style) seperti yang digambarkan.

\section{PARADIGMA PENELITIAN}

Metode penelitian yang digunakan dalam jurnal penelitian ini adalah dengan menggunakan penelitian kualitatif melalui analisis teks media iklan promosi di media sosial dengan memaknai tanda dan simbol pada media. Paradigma penelitian yang digunakan dalam penelitian ini menggunakan paradigma kritis. Paradigma ini ingin mengoreksi pandangan konstruktivisme yang kurang sensitive pada proses produksi dan reproduksi makna yang terjadi secara historis maupun institusional. Paradigma kritis, sebagai suatu tradisi intelektual dengan seperangkat keyakinan dalam melihat sebuah fenomena permasalahan secara kritis dengan membedah ideologi, dan sebagai bentuk pencerahan (enlightment) produsen melalui teks maupun konteks produk di dalam pemuatannya pada media iklan promosi di media sosial.

Pendekatan Kritis adalah pemahaman pengetahuan yang berhubungan dengan kekuasaan. Para peneliti pendekatan kritis percaya bahwa mereka yang berkuasa membentuk pengetahuan dengan cara mengabdikan status quo. Dengan demikian, orang-orang yang berkuasa berusaha menjaga kekuasaan mereka, sambil membungkam suara-suara minoritas yang mempertanyakan distribusi kekuasaan dan kebenaran versi pemegang kekuasaan.

\section{TEKNIK PENGUMPULAN DATA}

Pengumpulan data pada jurnal penelitian ini, peneliti menggunakan korpus materi iklan promosi di media sosial yang termuat di Instagram dengan produsen produk busana (fashion) Roughneck dan produk kosmetika Nature Republic yang masing-masing 1 sampel yang diteliti dengan materi iklan yang telah dipilih oleh peneliti.

\section{TEKNIK ANALISIS DATA}

Teknik analisis data yang digunakan pada penelitian ini menggunakan analisis semiotika model Ferdinand De Sassure dan deskripsi penyajian data melalui hasil wawancara dengan Informan yaitu salah satu endorse produk lokal di Indonesia. 


\section{STUDY KASUS}

\section{Iklan veet}

Veet merupakan produk untuk menghilangkan bulu di kulit, tapi bintang iklannya, Astrid Tyar, memang sudah memiliki kulit yang halus dan tanpa bulu. Seharusnya, untuk lebih meyakinkan, mereka menggunakan bintang iklan yang benar-benar berbulu, agar konsumen pun bisa yakin. 


\section{BAB III \\ PENUTUP}

\section{KESIMPULAN}

Dalam jurnal tersebut membahas tentang fashion endorse pada produk kosmetik dan busana pada remaja di media sosial Instagram. Upaya memenangkan persaingan bisnis tersebut, maka produsen baju pun berlomba-lomba untuk membuat media promosi dengan desain iklan yang menarik dimedia digital, eye catching serta menggunakan model-model yang memiliki perawakan dari wajah atau badan yang sesuai dengan penangkapan kamera atau dikenal dengan istilah camera face dan memiliki perawakan yang menjual. Sehingga dengan begitu dapat mendukung produk agar mudah terjual dengan terus mendengungkan brand (merek) produk di media komunikasi massa digital karena ada ketertarikan konsumen atau calon konsumen terhadap model ataupun produk yang dijual.

\section{SARAN}

Makalah review jurnal ini masih belum sempurna. Adapun saran-saran yang dapat ditujukan kepada diri sendiri,istitusi,peneliti lain,serta pembaca pada umumnya mengenai bagaimana mengantisipasi,menghindarkan atau memperkecil kendala yang dihadapi selama proses pengkajian atau analisis objek kajian. 


\section{DAFTAR PUSTAKA}

(Gora and Olifia)Gora, Radi, and Sandra Olifia. "Komodifikasi Model Endorse Dalam Industri Budaya Fashion Dan Kosmetika.” Ilmu Komunikasi, 2018, p. 14.

Littlejohn, Stephen W., and Karen A. Foss. Teori Komunikasi. Edited by Ria Oktafiani, 9th ed., Salemba Humanika, 2014.

(Littlejohn and Foss)Gora, Radi, and Sandra Olifia. "Komodifikasi Model Endorse Dalam Industri Budaya Fashion Dan Kosmetika.” Ilmu Komunikasi, 2018, p. 14.

Littlejohn, Stephen W., and Karen A. Foss. Teori Komunikasi. Edited by Ria Oktafiani, 9th ed., Salemba Humanika, 2014. 